\title{
AKTIVITAS DIPLOMASI DIGITAL DALAM MANAJEMEN BENCANA: STUDI KASUS DI DAERAH ISTIMEWA YOGYAKARTA, INDONESIA DAN FUKUSHIMA, JEPANG
}

\author{
Tiffany Setyo Pratiwi dan Hidayat Chusnul Chotimah \\ Prodi Ilmu Hubungan Internasional \\ Universitas Teknologi Yogyakarta
}

E-mail: tiffany.pratiwi@staff.uty.ac.id

\begin{abstract}
ABSTRAK
Penelitian ini membahas aktivitas diplomasi digital dalam manajemen bencana di Daerah Istimewa Yogyakarta dan Fukushima. Penelitian ini fokus pada tiga pokok bahasan: kebijakan penanggulangan bencana, peran lembaga pemerintahan dalam manajemen bencana, dan komparasi aktivitas diplomasi digital melalui twitter dalam 3 tahapan manajemen bencana, yakni pra bencana, pada saat terjadinya bencana, dan pasca bencana. Penelitian ini menggunakan konsep diplomasi digital dengan metodologi penelitian kualitatif. Teknik pengumpulan data melalui wawancara langsung, penulis juga menggunakan data sekunder yang berasal dari website resmi pemerintah, jurnal, dan berita online. Penelitian ini menemukan bahwa aktivitas diplomasi digital dalam manajemen bencana di DIY dan Jepang dilakukan secara terstruktur di lembaga pemerintahan. Aktivitas diplomasi digital di kedua bencana sama-sama memanfaatkan media sosial berupa twitter melalui media sosial, dan di dukung dengan website dan aplikasi yang dibuat oleh pemerintah. Di DIY menggunakan platform Whatshaap sebagai komunikasi virtual, sedangkan di Jepang menggunakan platform Line. Penelitian ini menemukan bahwa aktivitas diplomasi digital melalui twitter di DIY terjadi pasca bencana letusan gunung Merapi 2010 dan mitigasi bencana untuk mengantisipasi erupsi berikutnya dengan akun @pusdalopssleman dan @BPPTKG, sedangkan pada saat gempa bumi di Jepang tahun 2011 paling masif digunakan pada tahapan proses tanggap darurat sebagai respon membantu para korban dengan akun pemerintah @JPN_PMO.
\end{abstract}

Kata Kunci: Diplomasi Digital, Media Sosial, Manajemen Bencana, Daerah Istimewa Yogyakarta, Jepang

\section{ABSTRACT}

This research discusses about digital diplomacy activities in disaster management at Yogyakarta and Fukushima. This study focuses on three topics, such as: disaster management policies, the role of government agencies in disaster management, and explains the comparation the digital diplomacy activities by using social media in three stages of disaster management, such as: pre-disaster, during a disaster, and post-disaster. This study uses the concept of digital diplomacy with a qualitative research methodology. Data collection techniques are through direct interviews, author also uses secondary data derived from official government websites, journals, and online news. This study found that digital diplomacy activities in disaster management in DIY and Japan did in government agencies structurally. This study also found that digital diplomacy activities on disaster management through social media was carried out via Twitter massively, also using website or application made by government. For virtual communication in Yogyakarta using the Whatshaap platform while in Japan using the Line platform. This study found that digital diplomacy activities through social media in DIY occurred after the 2010 Mount Merapi eruption and disaster mitigation to anticipate the next eruption with @pusdalopssleman and @BPPTKG accounts. In Fukushima Japan, twitter used during the emergency response process by giving and receiving information from citizenswith @JPN_PMO account.

Keywords: Digital Diplomacy, Social Media, Disaster Management, Daerah Istimewa Yogyakarta, Japan 


\section{PENDAHULUAN}

Penelitian ini akan membahas mengenai aktivitas diplomasi digital dalam manajemen bencana di Indonesia dengan mengambil studi kasus di Daerah Istimewa Yogyakarta dan membandingkannya aktivitas diplomasi digital yang ada di Jepang. Kedua negara ini memiliki tingkat rawan bencana yang tinggi baik secara geologis maupun geografis. Dilihat dari aspek geologis, Indonesia berada pada titik temu lempeng bumi yang masih aktif, yaitu Eurasia, Indo Australia, Filipina, dan Pasifik sehingga rawan terhadap bencana alam seperti gempa bumi, tsunami, dan letusan gunung api. Sementara secara geografis, letak Indonesia yang berada diantara dua samudera dan dua benua menempatkan negara ini beresiko terkena bencana banjir, tanah longsor, banjir bandang, kekeringan, cuaca ekstrim dan abrasi serta dapat memicu kebakaran hutan dan lahan (BNPB, 2019). Sedangkan di Jepang sendiri, Jepang merupakan negara yang sangat rentan terhadap bencana alam karena iklim dan topografinya, dan telah mengalami gempa bumi, tsunami, angin topan, dan jenis bencana lainnya yang tak terhitung jumlahnya (Great East Japan Earthquake, 2011).

DI DIY sendiri pernah terjadi gempa yang dengan skala cukup besar. Pusat gempa ini terjadi di selatan Kota Yogyakarta yaitu Kabupaten Bantul pada tanggal 27 Mei 2006 dan menurut data Bakornas PB per tanggal 15 Juni 2006, telah menelan korban jiwa lebih dari 5.749 orang dan korban luka-luka 38.568 orang, serta ratusan ribu orang kehilangan tempat tinggal. Perkiraan dampak terhadap ekonomi sendiri mencapai kerugian senilai Rp. 29,2 Triliun (Bappenas \& Bakornas PB, 2006). Di Jepang sendiri korban meninggal akibat bencana tercatat dalam 10 tahun terakhir yang melanda paling dahsyat adalah gempa dengan 9.0 skala richter yang disusul gelombang tsunami tahun 2011 di Tohoku yang menewaskan hampir 20.000 orang, dan mengakibatkan 118.480 rumah runtuh total dan kerusakan sebagian pada 179.697 rumah (Dunbar, 2011).

Dalam perjalanannya, pemerintah DIY sudah banyak melakukan upaya untuk mengatasi dan menanggulangi, ataupun merespon jika terjadi bencana dan juga membangun budaya sadar bencana. Pemerintah daerah secara masif memanfaatkan media sosial dalam menyalurkan informasi sebagai bentuk diplomasi publik dalam kerangka diplomasi digital. Media sosial dapat menjadi sarana untuk menjalin komunikasi dengan keluarga dan teman dari para korban bencana. Di sisi lain, media sosial dapat pula menjadi sarana untuk menyediakan akses informasi seperti makanan, tempat tinggal atau bantuan medis. Hal ini juga ditujukan tidak hanya bagi masyarakat setempat yang berada di wilayah tersebut, tetapi juga menginformasikan kepada masyarakat internasional untuk dapat ikut serta merespon bencana yang terjadi di negara lain secara cepat (Lennah, 2012).

Penulis sangat tertarik melakukan studi komparasi DIY dalam merespon bencana khususnya dengan pemanfaatan diplomasi digital, dengan Jepang sebagai negara yang sangat baik dalam penanganan bencana dan menjadi pioner dalam penggunaan media sosial dalam hal kebencanaan. Seperti yang disebutkan Hanson bahwa tujuan penting diplomasi digital adalah untuk merespon terjadinya bencana (disaster response) di suatu negara dengan memanfaatkan kecanggihan teknologi komunikasi melalui perangkat media sosial 
seperti Facebook dan Twitter (Adesina, 2017). Oleh sebab itu, tulisan ini akan menganalisis lebih jauh mengenai aktivitas diplomasi digital dalam manajemen bencana di Indonesia dengan mengambil studi kasus di Daerah Istimewa Yogyakarta, Indonesia dan menjelaskan perbandingan aktivitas diplomasi digital yang ada di Fukushima, Jepang. Adapun penelitian ini memfokuskan pada media sosial dengan platform twitter.

\section{KERANGKA PEMIKIRAN}

\section{Konsep Diplomasi Digital}

Aktivitas diplomasi secara tradisional seringkali dikaitkan dengan tindakan para utusan (seperti duta besar, diplomat, maupun utusan lainnya) dari suatu negara dalam membangun hubungan internasional dengan negara lain (Nicolson, 1950). Pelaku dari aktivitas diplomasi sendiri mengalami perluasan yang tidak hanya melibatkan aktor dari utusan pemerintah saja, tetapi juga mencakup banyak pihak seperti selebriti, media, pelaku seni, kelompok agama, tim olahraga, maupun warga negara biasa lainnya (Kelman, 2017). Dengan adanya perkembangan teknologi informatika, aktifitas diplomasi pun mengalami evolusi dari yang bersifat tradisional berubah menjadi diplomasi modern. Westcost, misalnya, meneliti tentang dampak dari penggunaan internet terhadap hubungan internasional sehingga kemudian memunculkan istilah diplomasi digital (Westcott, 2008). Peneliti lain seperti Ronit Kampf, Ilan Manor dan Elad Segev (Kampf et al., 2015); Corneliu Bjola (Bjola, 2016); Jan Melissen dan Matthew Caesar-Gordon (Melissen \& Caesar-Gordon, 2016) juga mengkaji tentang pelaksanaan dari diplomasi digital dalam hubungan internasional.

Diplomasi digital atau yang dikenal juga dengan sebutan e-diplomacy termasuk dalam diplomasi modern. Hanson menjelaskan makna sederhana dari diplomasi digital sebagai penggunaan internet dan pemanfaatan teknologi informasi komunikasi baru untuk tujuan-tujuan diplomatik. Hanson membagi delapan capaian kebijakan untuk diplomasi digital, sebagai berikut (Adesina, 2017):

1. Manajemen pengetahuan (Knowledge Management), sebagai penguat pengetahuan pemerintah yang bertujuan memaksimalkan kepentingan nasional.

2. Diplomasi publik, untuk menjaga hubungan terhadap masyarakat yang di dalam maupun luar negeri serta mempengaruhi mereka lewat jejaring internet dengan tujuan-tujuan penting sebuah negara.

3. Manajemen informasi (Information Management), berfungsi mengumpulkan arusinformasi dan memberikan informasi kepada masyarakat mengenai pembuatan kebijakan serta membantu mengantisipasi dan menanggapi gerakan sosial dan politik yang muncul.

4. Consular Communication and Response, bertujuan untuk menciptakan komunikasi langsung secara privat kepada masyarakat yang tidak terjangkau di wilayah negara karena berada di negara lain, khususnya dalam situasi krisis. 
5. Merespon Bencana (Disaster Response), memperkuat konektivitas teknologi yang bisa digunakan dalam merespon situasi bencana.

6. Internet Freedom, menjaga akses internet terbuka dan free, hal tersebut berkorelasi dengan tujuan-tujuan mempromosikan kebebasan berbicara dan demokrasi suatu negara dibawah rezim yang otoriter.

7. Sumber daya eksternal (External Resources), menciptakan mekanisme digital yang juga memanfaatkan keahlian eksternal untuk tujuan nasional.

8. Perencanaan kebijakan (Policy Planning), memungkinkan untuk pengawasan dan koordinasi yang efektif lintas pemerintah di level internasional, sebagai tanggapan internasionalisasi birokrasi.

Keuntungan-keuntungan yang diperoleh dari aktivitas diplomasi digital dijelaskan oleh Verrikia (2017) adalah terciptanya komunikasi dua arah. Perkembangan media sosial seperti Facebook dan Twitter membuka secara luas ruang bagi pemerintah dan masyarakat untuk bisa berinteraksi. Sehingga pemerintah memahami dan mampu memetakan bagaimana opini publik yang sedang terjadi. Perkembangan yang tak kalah penting juga dipaparkan Verrikia bahwa peran diplomat tidak lagi monopoli karena sudah bisa digantikan dengan aktor non negara. Keterbukaan informasi berdampak pada transparansi segala kegiatan diplomatik yang dijalankan suatu negara yang secara langsung menekan biaya dan mengurangi pencemaran lingkungan. Misalnya saja para diplomat tidak perlu melakukan perjalanan menggunakan pesawat selama Skype bisa mewakili rapat antar negara (Verrekia, 2017).

Bjola menjelaskan untuk memetakan aktivitas diplomasi digital bisa di analisa dari tiga tahapan (Bjola \& Jiang, 2015):

1. Agenda Setting, tahapan dimana platform media sosial memungkinkan diplomat atau pihak pemerintah untuk mengatur agenda yang mau dilaksanakan. Hal ini menjadi penting karena penyebaran informasi dalam diplomasi digital merupakan sarana mengarahkan topik-topik tertentu kepada target agar tujuan sebuah negara tercapai.

2. Presence-Expansion, tahapan dimana agenda yang dicanangkan telah tersampaikan ke target, kemudian telah nampak seperti apa tanggapan, reaksi, masukan, ataupun perspektif dari yang ditargetkan (masyarakat). Bentuk tanggapan, reaksi, masukan ataupun perspektif bisa diamati lewat jumlah reposting ataupun commenting dari target.

3. Conversation Generating, tahapan dimana antara pemahaman dan tujuan pengirim pesan (message sender) dalam hal ini pemerintah kepada yang menerima pesan sama, walaupun dimungkinkan belum secara penuh dipahami. Tahapan ini juga adalah tahapan dimana pengirim pesan memberikan umpan balik (providing feedback) ke target. Komunikasi yang terjalin tidak monolog melainkan dalam tahap ini sudah terjadi dialog. 


\section{a. Manajemen Bencana}

Mengacu definisi dari United Nations International Strategy for Disaster Reduction (UNISDR), bencana didefinisikan sebagai suatu gangguan serius yang mengakibatkan timbulnya kerugian bagi kehidupan manusia baik kerugian materi, ekonomi maupun lingkungan, di luar kapabilitas sumber daya yang dimiliki komunitas masyarakat untuk mengatasi gangguan tersebut (United Nations International Strategy for Disaster Reduction (UNISDR, 2009). Shaluf menyebutkan bahwa bencana dibagi menjadi tiga kategori yaitu natural disaster (bencana alam), man-made disasters (bencana yang diakibatkan oleh manusia) dan hybrid disasters. Dalam penelitian ini, peneliti membahas tentang bencana alam yaitu peristiwa bencana yang diakibatkan oleh alam, yang terkait dengan permukaan bawah bumi, topografi, meteorologi, hidrologi dan biologis, di luar kendali manusia (Shaluf, 2007).

Manajemen bencana merupakan upaya-upaya yang dilakukan guna mengurangi risiko dari bencana yang akan terjadi. Terdapat empat komponen dalam manajemen bencana (Coppola, 2011), yaitu:

a. Mitigasi, adalah upaya mengurangi atau mengeliminasi risiko bencana.

b. Kesiapsiagaan, adalah memperlengkapi masyarakat yang berpotensi terdampak bencana dan menekan kerugian mereka.

c. Respon, adalah mengambil tindakan untuk mengurangi dampak bencana, tindakan ini mencegah agar tidak terjadinya penderitaan lebih lama.

d. Pemulihan, adalah mengembalikan kehidupan korban seperti sedia kala, dan memakan waktu bertahun-tahun.

\section{METODE PENELITIAN}

Jenis penelitian yang digunakan dalam penelitian ini adalah penelitian kualitatif. Penelitian kualitatif dilakukan melalui pencarian sebuah jawaban dari individu/kelompok dalam setting sosial (Lune \& Berg, 2017). Setting sosial yang dimaksud adalah peran diplomasi digital dalam manajemen bencana di Daerah Istimewa Yogyakarta. Penelitian ini menggunakan salah satu jenis penelitian kualitatif yaitu pendekatan studi kasus karena penelitian ini terjadi di lokasi Daerah Istimewa Yogyakarta yang mengalami kejadian bencana alam. Yin menjelaskan bahwa penelitian studi kasus menyelidiki fenomena kontemporer (kasus) dalam konteks dunia nyata (Yin, 2015).

Teknik pengumpulan data yang dilakukan oleh peneliti yaitu melalui studi pustaka dari literaturliteratur sebelumnya yang relevan dengan topik tentang peran diplomasi digital dan manajemen bencana maupun dari laporan-laporan dari lembaga resmi secara daring. Selain itu, peneliti juga melakukan wawancara langsung tatap muka dan melalui perangkat aplikasi Zoom dengan narasumber yang berasal dari Badan Penanggulangan Bencana Daerah (BPBD) Sleman, Badan Meteorologi Klimatologi dan Geofisika (BMKG), dan Peneliti/Akademisi Kebencanaan Jepang dari Osaka University. 


\section{PEMBAHASAN}

\section{Kebijakan Penanggulangan Bencana Di Indonesia Dan Jepang}

a. Indonesia

Di Indonesia Badan Nasional Penanggulangan Bencana atau BNPB berada di bawah Presiden langsung. BNPB merupakan lembaga setingkat kementerian, yang disahkan tahun 2007. Penanggulangan atau manajemen bencana di Indonesia secara terpadu di atur dalam acuan Rencana Nasional Penanggulangan Bencana 2015-2019 yang kemudian dituangkan ke dalam Rencana Kerja (RENJA) hingga ke tingkat daerah yang disebut dengan Rencana Penanggulangan Bencana Daerah (RPBD). Di tingkat BNPB, Peraturan Kepala (PERKA) BNPB diberlakukan pada penanggulangan bencana, seperti: Kedaruratan diatur dalam Perka BNPB 03 Tahun 2016 Tentang Sistem Komando Penanganan Darurat Bencana. Pasca Bencana misalnya ada di Perka Rencana 05 Tahun 2017 tentang Penyusunan Rencana Rehabilitasi dan Rekonstruksi dan Perka 06 Tahun 2017 tentang Penyelenggaraan Rehabilitasi dan Rekonstruksi Pascabencana (bnpb.go.id).

Bencana alam yang sering terjadi dengan resiko tinggi di Indonesia diantaranya: gempa bumi, tsunami, letusan gunung api, tanah longsor, banjir, banjir bandang, kekeringan, cuaca ekstrim, gelombang ekstrim dan abrasi, kebakaran hutan dan lahan, epidemi dan wabah penyakit. Dengan jenis-jenis bencana alam yang beragam ini, Renas Penanggulangan Bencana di atur secara berkala selama lima tahunan untuk selalu di perbaiki setiap Renasnya. Sedangkan kebijakan penanggulangan bencana atau mekanisme penanganan bencana mengacu pada Undang-Undang No. 24 tahun 2007 tentang Penanggulangan Bencana dan Peraturan Pemerintah No. 21 tahun 2008 tentang Penyelenggaraan Penanggulangan Bencana. Rencana Penanggulangan Bencana Daerah (RPBD) Daerah Istimewa Yogyakarta tahun 2013-2017 dengan Peraturan Gubernur DIY Nomor 81 Tahun 2013. Rencana Penanggulangan Bencana Daerah adalah dokumen perencanaan yang berisi strategi, program dan pilihan tindakan dalam penyelenggaraan penanggulangan bencana dari tahap pra, tanggap darurat, dan pascabencana (peraturan.bpk.go.id). Dalam pergub tersebut dijelaskan visi penanggulangan bencana DIY yakni: "Masyarakat Daerah Istimewa Yogyakarta yang Peka, Tanggap, dan Tangguh terhadap Bencana dalam Menyongsong Peradaban Baru", dengan menjunjung prinsip-prinsip: cepat dan tepat; prioritas; koordinasi dan keterpaduan; berdaya guna dan berhasil guna; transparansi dan akuntabilitas; kemitraan; pemberdayaan; non-diskriminatif; dan nonproletisi.

Pada tahun 2010 Provinsi DIY diguncang letusan Gunung Merapi. Bila dibandingkan dengan bencana serupa pada tahun 1994, 1997, 1998, 2001 dan 2006, bencana ini lebih besar baik dari skala maupun dampaknya. Berdasarkan data dari BNPB per 31 Desember 2010, erupsi ini telah menimbulkan kerusakan dan kerugian sebesar Rp. 3.628 Triliun, di mana sektor ekonomi produktif mengalami dampak terbesar yaitu sebesar Rp. 1,692 triliun (46,64\%). Selanjutnya, disusul oleh sektor infrastruktur sebesar Rp. 707,427 miliar (19,50\%), sektor perumahan Rp. 626,651 miliar (17,27\%), lintas sektor Rp. 408,758 miliar 
(13.22\%), dan sektor sosial Rp. 122,472 miliar (3,38\%) (BNPB \& BAPPENAS, 2011). Melihat bencana-bencana yang terjadi di Daerah Istimewa Yogyakarta telah menempatkan provinsi ini sebagai daerah dengan indeks rawan bencana yang tinggi di tahun 2008 (BNPB, 2011). Namun kemudian pada tahun 2018, indeks rawan bencana di provinsi ini mengalami penurunan pada level sedang (BNPB, 2019); sehingga dalam mengatasi berbagai bencana alam yang terjadi pada tingkat daerah ini dibutuhkan perangkat daerah yang bertugas langsung menangani kondisi di lapangan, yang selanjutnya secara kontinu berkoordinasi hingga tingkat pusat. Secara organisatoris urutan kelembagaan kebencanaan di Indonesia terdiri atas: 1. Badan Nasional Penanggulangan Bencana Tingkat Pusat, 2. Badan Penanggulangan Bencana Daerah Tingkat Provinsi, dan 3. Badan Penanggulangan Bencana Daerah Tingkat Kabupaten/Kota. Untuk Daerah Istimewa Yogyakarta sendiri, di tingkat provinsi terdapat Badan Penanggulangan Bencana Daerah DIY yang beralamat di Jalan Kenari No. 14A, Semaki, Umbulharjo, Yogyakarta. Terdapat lima BPBD Kabupaten/Kota di DIY, yakni: BPBD Sleman, BPBD Bantul, BPBD Kota Yogyakarta, BPBD Gunungkidul, dan BPBD Kulon Progo.

b. Jepang

Agak berbeda dengan Indonesia, Jepang memiliki kementerian sendiri yang menangani bencana, Kementerian Penanggulangan Bencana atau Minister of State for Disaster Management yang terbentuk sejak tahun 1984. Kementerian ini langsung dibawah Perdana Menteri Jepang. Penanganan bencana di Jepang mengacu pada UU Disaster Countermeasures Basic Act yakni Undang-undang Dasar Penanggulangan Bencana. Undang-Undang Dasar Penanggulangan Bencana ini menjadi aturan bagi semua fase manajemen bencana dari pencegahan, mitigasi dan kesiapsiagaan, tanggap darurat, pemulihan dan rekonstruksi, yang mana peran dan tanggung jawabnya terletak pada pemerintah pusat dan daerah, serta entitas yang relevan dari sektor publik dan swasta yang akan bekerja sama melaksanakan berbagai penanggulangan bencana (Cabinet Office, Government of Japan, 2015: 6). Perencanaan manajemen bencana di Jepang terdiri atas proses berikut (Cabinet Office, Government of Japan, 2015: 8-9):

i. Basic Disaster Management Plan, di tahap ini merupakan level paling tinggi dalam aktivitas perencanaan manajemen bencana, tahapan ini dipersiapkan oleh Dewan Penanggulangan Bencana Pusat atau Central Disaster Management Council, yang mana di dalam dewan ini terdiri atas: Perdana Menteri dan Menteri Negara Manajemen Bencana sebagai ketua, dan kepala perusahaan sektor publik dan para ahli sebagai anggota yang menawarkan pendapat untuk perencanaan manajemen bencana. Perencanaan manajemen bencana ini harus berdasarkan UU Dasar Penanggulangan Bencana atau Disaster Countermeasures Basic Act.

ii. Disaster Management Operation Plan, dikelola oleh pemerintah dan perusahaan publik berdasarkan Basic Disaster Management Plan.

iii. Local Disaster Management Plan, dikelola oleh badan penanggulangan bencana di tingkat daerah/kota berdasarkan Basic Disaster Management Plan. 
iv. Community Disaster Management Plan, dikelola oleh masyarakat dan sektor bisnis secara sukarela.

Baik di Jepang dan Indonesia, penanganan manajemen bencana dalam skala kerusakan besar sama-sama akan dikelola oleh pusat atau disebut sebagai bencana nasional. Sebagai contoh di Indonesia, ketika terjadi tsunami Aceh tahun 2004, yakni melalui Keputusan Presiden Nomor 112 Tahun 2004 tentang Penetapan Bencana Alam Gempa Bumi dan Gelombang Tsunami di Provinsi Nanggroe Aceh Darussalam dan Provinsi Sumatera Utara sebagai bencana nasional. Hal yang sama terjadi di Jepang ketika bencana gempa bumi dan tsunami Tohoku tahun 2011 yang juga mengakibatkan ledakan dan kehancuran tiga reaktor di stasiun nuklir di Fukushima, bencana dahsyat ini di ambil alih oleh pusat dibawah Perdana Menteri Jepang.

\section{Penggunaan Sosial Media Sebagai Alat Aktivitas Diplomasi Digital}

a. Penggunaan Media Sosial dalam Kebencanaan di Daerah Istimewa Yogyakarta

Dalam manajamen bencana terdapat fase pra bencana seperti mitigasi dan kesiapsiagaan, saat bencana yakni tanggap darurat, dan pasca bencana seperti rekonstruksi dan rehabilitasi. Ketiga fase ini memerlukan banyak unsur pendukung. Salah satu unsur pendukung di BPBD DIY yakni Pusat Pengendalian Operasi Penanggulangan Bencana atau disingkat Pusdalops DIY Penanggulangan Bencana merupakan unsur pelaksana operasional pada Pemerintah Pusat dan Daerah, yang bertugas memfasilitasi pengendalian operasi serta menyelenggarakan sistem informasi dan komunikasi kepada masyarakat. Bidang ini mengelola penggunaan sosial media pada tiap fase bencana. Tugas pokok Pusdalops pada saat pra bencana dengan memberikan dukungan kegiatan pada saat sebelum terjadinya bencana secara rutin. Ketika bencana terjadi, Pusdalops memberikan dukungan pada Posko Tanggap Darurat dan Pelaksanaan Kegiatan Darurat. Pada pasca bencana, Pusdalops memberikan dukungan kegiatan pada saat setelah bencana terjadi seperti penyedia data dan informasi untuk rehabilitasi dan rekonstruksi (BPBD, 2019). Berikut adalah nama-nama akun media sosial di BPBD DIY yang dikelola Pusdalops:

\begin{tabular}{|c|l|l|l|l|}
\hline No. & $\begin{array}{l}\text { BPBD Provinsi dan } \\
\text { Kabupaten/Kota }\end{array}$ & Akun Twitter & Akun Facebook & Akun Instagram \\
\hline 1. & BPBD DIY & @Pusdalops_diy & Pusdalops BPBD DIY & @bpbd_diy \\
\hline 2. & $\begin{array}{l}\text { BPBD Kota } \\
\text { Yogyakarta }\end{array}$ & @pusdalopsktjogj & BPBD Kota Yogyakarta & @bpbdkotajogja \\
\hline 3. & BPBD Sleman & @pusdalopssleman & $\begin{array}{l}\text { Pusdalops BPBD } \\
\text { Kabupaten Sleman }\end{array}$ & @pusdalopssleman \\
\hline 4. & BPBD Bantul & @PusdalopsBantul & BPBD Kabupaten Bantul & @pusdalopsbantul \\
\hline
\end{tabular}




\begin{tabular}{|c|l|l|l|l|}
\hline 5. & BPBD Gunung Kidul & $@ b p b d \_g k$ & BPBD Gunungkidul & @bpbd_gk \\
\hline 6. & BPBD Kulon Progo & @BPBDKulonProgo & - & - \\
\hline
\end{tabular}

Berdasarkan data Pusdalops BNPB bencana erupsi Gunung Merapi menelan korban jiwa sebanyak 277 orang di DIY dan 109 di Jawa Tengah. Erupsi Gunung Merapi terjadi pada tanggal 26 Oktober 2010. Dalam aktivitas diplomasi digital tahapan awal adalah agenda setting, tahapan dimana platform media sosial memungkinkan diplomat atau pihak pemerintah untuk mengatur agenda yang mau dilaksanakan (Bjola \& Jiang, 2015). Media sosial yakni twitter sebagai alat dalam diplomasi digital kebencanaan baru digunakan pasca Erupsi Merapi oleh pemerintah. Proses sumber informasi aktivitas Merapi berasal dari Badan Penyelidikan dan Pengembangan Teknologi Kebencanaan Geologi (BPPTKG) Yogyakarta. Di mana BPPTKG Yogyakarta merupakan fasilitator, pengarah dan pemberi rekomendasi mengenai aktifitas Gunung Merapi kepada pemerintah, seperti BPBD Sleman. Sedangkan BPBD Sleman berperan sebagai pelaksana penanggulangan bencana dan penyebaran informasi kebencanaan agar sampai kepada masyarakat. Pada saat terjadinya erupsi tanggap darurat di situasi krisis pemerintah menggunakan alat seperti handy-talky (HT), radio, dan Whatshaap, sedangkan penggunaan twitter belum digunakan, baru memasuki tahun 2013 platform twitter dipergunakan secara kontinu. Pasca bencana agenda yang dirancang adalah "Laporan Aktivitas Gunung Merapi". Hingga saat ini, media sosial sangat berfungsi menyampaikan informasi secara berkelanjutan dan real time terkait aktivitas Merapi, yang diperuntukkan sebagai upaya mitigasi dan kesiapsiagaan bencana. BPBD secara terus menerus memberikan informasi melalui sosial media ataupun pertemuan tatap muka dengan salah satu tujuannya mengurangi tingkat kepanikan di saat krisis (Kushartati, 2020). Twitter BPBD DIY di buat tahun 2012, twitter BPBD Sleman di buat tahun 2015, dan twitter BPPTKG sendiri dibuat tahun 2013. Akan tetapi aktor seperti organisasi masyarakat yaitu Jalin Merapi telah lebih dulu menggunakan media seperti twitter dengan akun @jalinmerapi seperti pada Oktober 2010 dengan menggunakan hashtag \#NASBUNG (nasi bungkus) sebagai upaya mendapatkan bantuan ke pengungsi. Dengan menggunakan Twitter, informasi ini sangat cepat tersampaikan kepada donatur yang ingin membantu. Relawan yang ingin terjun ke lapangan juga mendapatkan informasi dari akun twitter jalin merapi yang saat ini memiliki followers 132.000 akun (Mahaswari, 2012). Hal ini dibenarkan oleh Ibu Asih Kushartati dalam wawancara dengan Penulis. Menurut beliau, kondisi saat bencana tidak terkendali sehingga relawan tanpa menunggu BPBD secara spontan langsung membantu para korban. 
Gambar 1. BPBD DIY me-retweeted cuitan dari BPPTKG

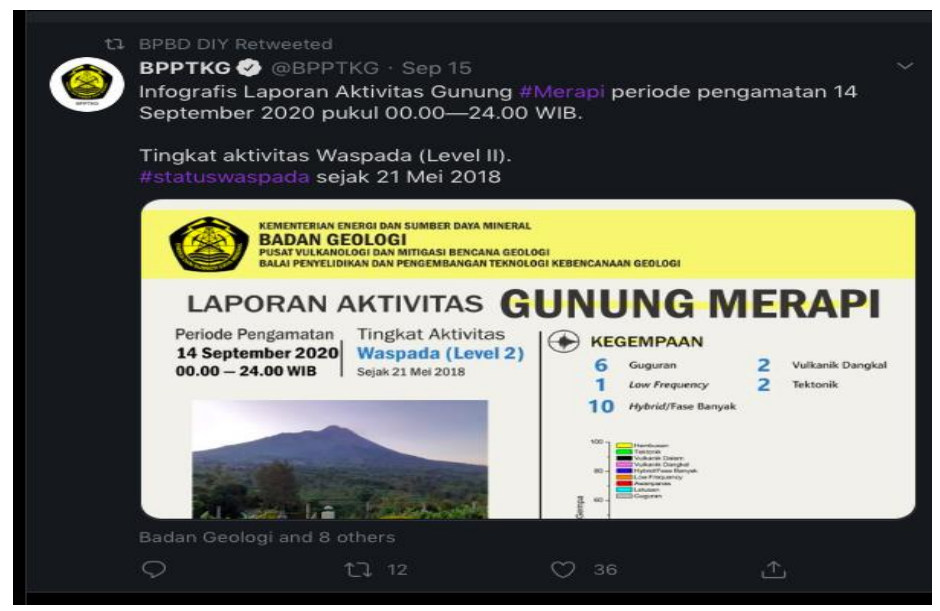

Sumber: www.twitter.com

Pelayanan BPDB baik ditingkat provinsi DIY dan Kabupaten/Kota membuka kerjasama lintas instansi dalam aktivitas diplomasi digital, seperti dari cuitan twitter Balai Penyelidikan dan Pengembangan Teknologi Kebencanaan Geologi (BPPTKG) tentang laporan aktivitas Gunung Merapi yang di retweet oleh BPBD DIY. Unsur pendukung lainnya adalah Badan Meteorologi Klimatologi dan Geofisika (BMKG) memberikan info prediksi terjadinya gempa bumi, tsunami, cuaca ekstrem, dan hujan angin. Peran BMKG dalam manajemen bencana ini berfokus pada mitigasi bencana dan biasanya akan menginfokan tandatanda alam yang bisa mengarah terjadinya potensi cuaca ekstrem, gempa bumi sehingga sebelum bencana terjadi diharapkan informasi dari BMKG akan diterima oleh BPBD sehingga akan berperan dalam pengurangan resiko bencana. Wewenang BMKG adalah monitoring gempa bumi dan membuat peringatan dini tsunami (Prakosa, 2020). Upaya diplomasi digital dalam menampung keluhan masyarakat selain lewat media sosial, juga dilakukan melalui 2 kanal, yaitu Lapor Sleman dan Lapor Bencana Sleman BPBD DIY. Pada lapor Sleman keluhan dari masyarakat ditanggapi oleh pegawai BPBD DIY yang nantinya akan menindaklanjuti keluhan yang disampaikan kemudian aplikasi Lapor Bencana Sleman sejak tahun 2019 dibuat oleh BPBD Sleman dan bisa diunduh di Play Store (Kushartati, 2020). Dari sini dapat dilihat bahwa diplomasi digital telah dilakukan oleh Pemerintah melalui aplikasi yang mempermudah masyarakat dalam berinteraksi kepada pemerintah pasca bencana erupsi 2010. 
Gambar 2. Jumlah orang yang melihat postingan BPBD Gambar 3. Aplikasi Lapor Bencana Sleman

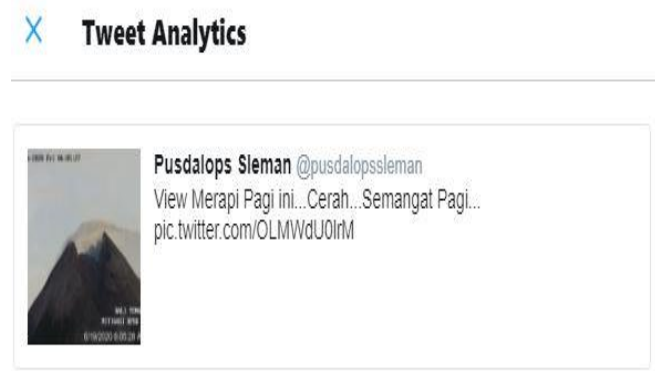

Impressions

times people saw this Tweet on Twitter

Total engagements

times people interacted with this Tweet

View all engagements

Sumber: www.twitter.com

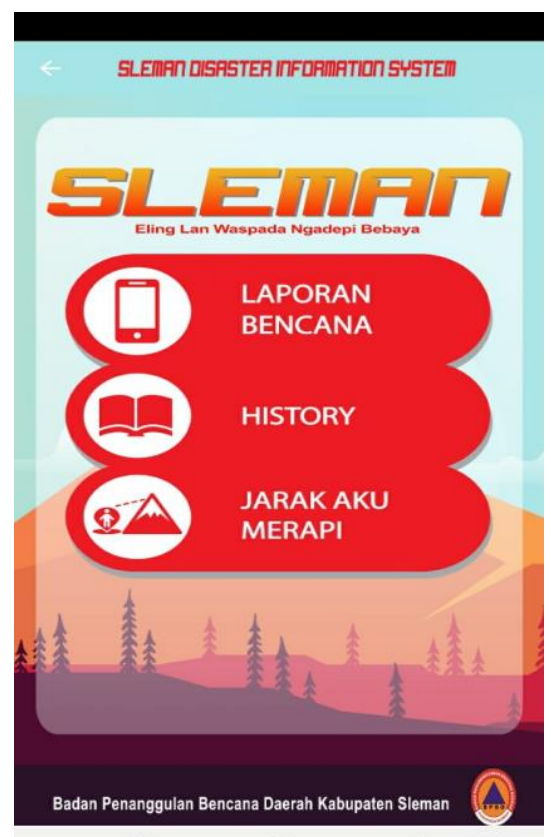

III

Sumber: play.google.com

Gambar 4. Contoh Agenda Informasi "Laporan Aktivitas Gunung Merapi" yang diposting BPPTKG di akun twitternya

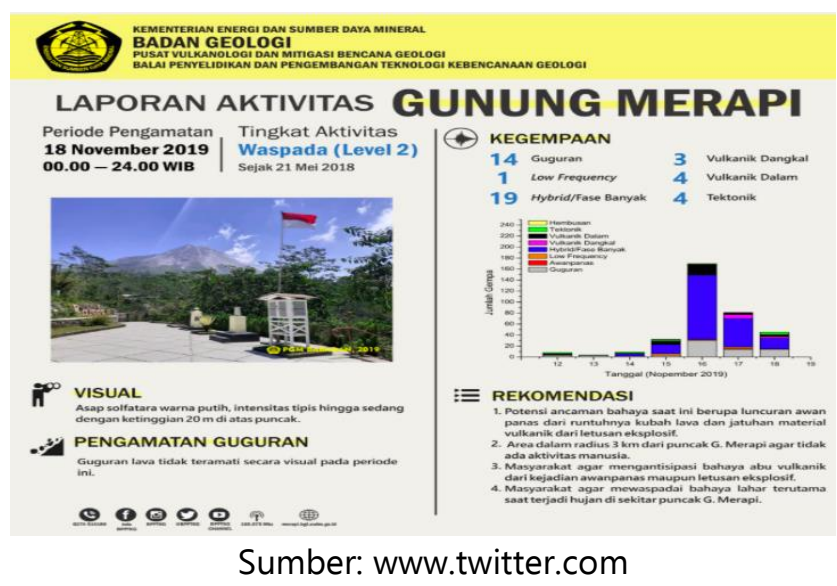

Gambar diatas adalah satu satu contoh cuitan di twitter yang memberikan informasi perkembangan Merapi. Sehingga dalam aktivitas diplomasi digital pada tahapan presence-expansion (Bjola \& Jiang, 2015), telah nampak tanggapan, reaksi, masukan, ataupun perspektif dari masyarakat yang menerima informasi pra bencana terkait kondisi Merapi. Bentuk tanggapan, reaksi, masukan ataupun perspektif bisa diamati lewat jumlah reposting ataupun commenting dari target. Cuitan twitter tersebut salah satu contoh masyarakat memberikan reaksi. Selain memiliki media sosial juga ada aplikasi website yang mendukung dalam manajemen bencana di http://bpbd.jogjaprov.go.id/lapor-bencana yang di dalamnya pelapor bisa 
melaporkan data bencana, korban jiwa, informasi pelapor/instansi, rumah rusak, pengungsian jiwa/KK, dan mengupload foto kondisi, kemudian pelapor mengirim pesan. Dari laporan ini, BPBD mendapatkan informasi dan memberikan bantuan ke masyarakat yang terdampak. Conversation generating, tahapan dimana antara pemahaman dan tujuan pengirim pesan (message sender) dalam hal ini pemerintah kepada yang menerima pesan sama, walaupun dimungkinkan belum secara penuh dipahami. Tahapan ini juga adalah tahapan dimana pengirim pesan memberikan umpan balik (providing feedback) ke target. Dalam tahap ini sudah terjadi dialog. Dalam conversation generating ini, seperti melakukan sosialisasi informasi status Merapi sejak 21 Juni 2018 dalam status waspada melalui twitter tersampaikan dengan baik ke masyarakat. Perubahan aktivitas Merapi dari Waspada ke Siaga (Level III) pada 5 November 2020 dilaporkan melalui twitter @BPPTKG dan di respon masyarakat dengan likes, comment, dan reposting.

Gambar 5. Informasi perubahan status Merapi di twitter BPPTKG

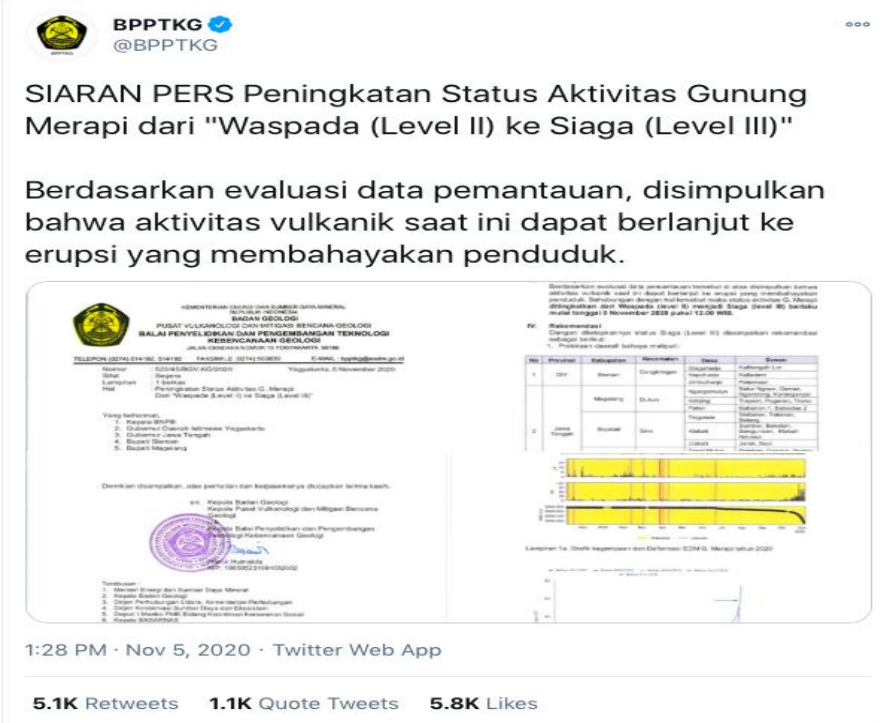

Sumber: www.twitter.com

Namun untuk memastikan bahwa masyarakat mampu sadar bencana dan tidak panik membutuhkan dukungan dari masyarakat yang sadar bencana, ketersediaan infrastruktur pendukung, dukungan anggaran yang memadai, dan teknologi untuk mendukung manajemen bencana. Masyarakat juga masih memakai alat-alat tradisional dalam tanggap darurat seperti kentongan. Pemerintah menggunakan handy-talky atau radio dalam memberikan informasi di situasi tanggap darurat.

\section{b. Penggunaan Media Sosial dalam Kebencanaan di Fukushima}

Pemanfaatan platform media sosial dalam aktivitas diplomasi digital dilakukan oleh Jepang pada gempa bumi Maret 2011 yang melanda daerah Jepang Timur atau dikenal dengan The Great East Japan Earthquake, salah satu yang terdampak hebat adalah Kota Fukushima. Pemerintah Jepang melakukan aktivitas diplomasi digital menggunakan beberapa media sosial, yakni: twitter dengan akun @JPN_PMO, 
facebook dengan akun @Japan.PMO, dan akun youtube PMOJapan dalam proses manajemen bencana alam The Great East Japan Earthquake. The Greast East Japan adalah pusat gempa bumi yang terjadi pada bulan Maret tahun 2011, menyebabkan hampir 15.000 ribu orang tewas, 3.000 jiwa menghilang, dan sekitar 6.000 orang terluka. Gempa bumi berskala 8.9 besarnya tersebut membuat stasiun nuklir di Fukushima bocor yang mengakibatkan hampir 470.000 orang di evakuasi dalam tiga hari (www.mofa.go.jp). Pada musibah bocornya nuklir ini, aktivitas diplomasi digital digalakkan oleh pemerintah Jepang. Gempa bumi ini juga disertai gelombang tsunami. Pada tingkat makro, pemerintah pusat dan media massa secara aktif menggunakan Twitter untuk mengirimkan informasi kepada warga. Di pemerintah daerah, media lokal dan kedutaan juga mengaktifkan akun Twitter dan berkomunikasi dengan penduduk dan anggota. Selain itu, blogger dan kurator secara aktif berkumpul dan mengirimkan pesan-pesan penting. Fungsi hashtag (\#) di Twitter memungkinkan pengguna mencari informasi dan mengunggah informasi terkait topik tertentu, seperti "tsunami" atau "kecelakaan nuklir". Multi-fungsi Twitter dan pemanfaatannya sebagai jaringan komunikasi adalah di antara alasan penting penggunaan Twitter secara luas dalam situasi bencana di Jepang tahun 2011 (Jung dan Moro, 2012; Marwick dan boyd, 2011 dalam tulisan Joo-Young Jung, 2012). Saat berita dan gambar menyebar secara online, tagar termasuk "\#prayforjapan", "\#earthquake" dan "\#tsunami" mulai menjadi tren di Twitter (Blackburn, 2011). Pemerintah bergerak sangat cepat setelah gempa bumi, Pasukan Bela Diri Jepang (Japan Self-Defense Force) memainkan peran penting dalam mengatur upaya bantuan terbesar dalam sejarah pascaperang. JSDF memulai operasi pencarian dan penyelamatan dan pertolongan hanya beberapa jam setelah gempa bumi dan tsunami. Pada 13 Maret, Perdana Menteri Naoto Kan memerintahkan mobilisasi 100.000 personel JSDF. Pada 17 Maret, sekitar 76.000 tentara JSDF dikerahkan dari pangkalan JSDF di seluruh Jepang dan terlibat dalam kegiatan seperti pencarian, penyelamatan dan pemulihan serta pengangkutan dan distribusi pasokan bantuan (www.stimson.org). Sehingga dalam menghadapi tanggap darurat, pemerintah Jepang bergerak cepat di saat situasi alat komunikasi mati, twitter platform media sosial yang berfungsi, akun @JPN_PMO dibuat pada saat bencana tersebut. Pemerintah Jepang menelusuri laporan-laporan yang masuk dari masyarakat. Manajemen penanganan bencana tahun 2011 tersebut yang di dukung dengan diplomasi digital lewat twitter tentu tidaklah cukup. Sehingga penanganan yang melibatkan personil Pasukan Bela Diri Jepang diterjunkan.

Media sosial menyediakan cara cepat dan mudah untuk memberikan kontribusi pada upaya bantuan saat gempa bumi terjadi. Sebagai contoh, Kota Iwaki di Fukushima mendapat perhatian publik karena bencana Nuklir Fukushima Daiichi yang mengakibatkan radiasi. Kota Iwaki berdekatan dengan pembangkit listrik tenaga nuklir yang rusak, sehingga risiko paparan radiasi menjadi problem tersendiri, yang mana membuat perusahaan, media, organisasi kemanusiaan ragu-ragu untuk memasuki Kota Iwaki dan sekitarnya. Namun, pada kondisi tersebut media sosial membuat perubahan. Rumah sakit menyebarluaskan video melalui Ustream, karena sangat membutuhkan tenaga medis, video tersebut 
mendapatkan perhatian luas yang akhirnya membuat dokter-dokter dan tenaga medis pergi ke Kota Iwaki secara sukarela membantu (Hashimoto dan Ohama, 2014). Disinilah salah satu bukti bahwa aktivitas diplomasi digital dalam merespon bencana atau disaster response yakni memperkuat konektivitas teknologi yang bisa digunakan dalam merespon situasi bencana dipratekkan (Hanson). Proses ini juga dalam aktivitas diplomasi digital yakni presence-expansion dan conversation generating terbentuk. Media sosial adalah alat pengumpulan informasi yang paling efektif dalam kasus di gempa bumi dan nuklir Fukushima. Hal ini terbukti di Twitter, yang secara otomatis men-tweet laporan gempa yang diterbitkan oleh National Research Institute dan Badan Meteorologi Jepang, telah menarik hampir 1.000.000 pengikut dan menempati peringkat ke-10 dengan jumlah total pengikut di Jepang (Hashimoto dan Ohama, 2014).

Gambar 6. Tampilan video yang diupload bulan April 2011 melaporkan keadaan pasca-bencana

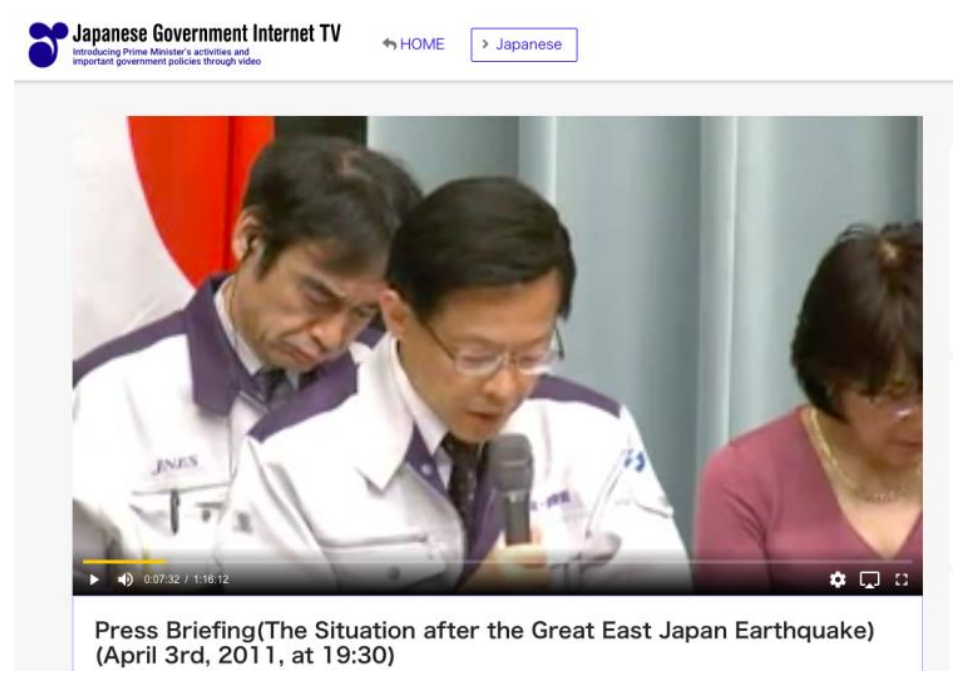

Sumber: nettv.gov-online.go.jp

Gambar diatas adalah sebuah video yang dirilis secara terjadwal oleh pemerintah Jepang melaporkan situasi setelah bencana, bernama Japanese Government Internet TV. Link video diposting di akun twitter @JPN_PMO setelah video rilis. Hal ini adalah bentuk informasi kepada masyarakat. Indonesia juga memiliki BNPB TV di link berikut http://tv.bnpb.go.id/front/searching, namun saat penulis mencari di bagian kolom search tidak ditemukan video bencana Merapi tahun 2010. Pada pasca bencana, menurut Survey Research Center (2011), internet menduduki peringkat ketiga (25,5 persen) setelah televisi NHK (53,7 persen) dan televisi komersial (30,6 persen) sebagai media yang berguna untuk mendapatkan informasi pasca gempa. National Hoso Kyoku (NHK) adalah stasiun televisi yang banyak di tonton warga Jepang untuk mendapatkan informasi pasca gempa bumi (Joo-Young Jung, 2012). Pasca bencana tanggal 12 Maret 2011, Twitter Blog melaporkan sebanyak 572.000 akun baru twitter yang dibuat. Di saat yang sama, ada sekitar 177 juta cuitan twitter soal gempa bumi Jepang di posting. Twitter juga memberikan informasi medis untuk korban dengan hashtag \#311 care (www.healthcareitnews.com). Hal ini sejalan dengan penjelasan Prof. Stefano Tsukamoto saat diwawancari Penulis, seorang peneliti kebencanaan dari Osaka Universtity, ia 
menyampaikan: "Do you know East Japan eartquake in 2011, about twenty thousand died in that time, you know, in that time every things shut down the electricity shut down, email we can not use email. But only facebook and twitter works, ya we so surprise and goverment recognize, oh facebook twitter work, and government start to use twitter and facebook, local government, NGO, from east japan earthquake. Facebook and twitter very strong in that time, also they victims, they try to use twitter and facebook to send SOS, by twitter. And then from earthquake area is about five hundred kilometer far from Tokyo, and Tokyo officer use that twitter for victims area" (Tsukamoto, 2020).

Prof. Tsukamoto menambahkan jika di Jepang platform komunikasi virtual yang populer di masyarakat adalah Line. Line difungsikan oleh Pemerintah Jepang untuk memberikan informasi ke warganya. "In Japan whatshaap not populer, Line more populer. In Japan, if earthquake happen, about twenty or thirthy seconds before earthquake, we receive information from Line, kind of early warning system. You know, there are two kind of wave, $p$-waves and s-waves, kind of earthquake wave. $P$-waves is going faster and s-waves slower shacking, p-waves faster, so in Japan our technology could catch p-waves. I think only Japan have this technology" (Tsukamoto, 2020).

Twitter adalah media sosial yang banyak di akses pada saat bencana di Fukushima. Di antara berbagai media sosial yang tersedia di Jepang, menggunakan Twitter jauh lebih cepat, karena platform tersebut memiliki kompatibilitas yang baik. Batas 140 karakter yang ada di Twitter mendukung tulisan Jepang, karena dapat memadatkan banyak informasi dengan batasan ini, dan sebenarnya mendorong pesan menjadi lebih sederhana dan mudah dipahami. White Paper of Information and Communication Jepang menyatakan bahwa twitter memainkan peran utama dalam menyebarkan informasi selama bencana di banyak komunitas, karena jumlah pengikut dan Tweet per hari dari 11 akun Twitter pemerintah daerah yang terkena bencana dan 28 akun Twitter dari pemerintah lokal masing-masing meningkat sepuluh kali lipat setelah 11 Maret 2011 (Kaigo, 2012).

\section{Studi Komparasi Aktivitas Diplomasi Digital dalam Hal Kebencanaan di DIY dan Jepang}

Jepang adalah negara pioner yang memanfaatkan media sosial berupa twitter dalam aktivitas diplomasi digital kebencanaan. Pemerintah Jepang menggunakan twitter sebagai aktivitas diplomasi digital dengan akun @JPN_PMO. Sedangkan Pemerintah di Daerah Istimewa Yogyakarta, media sosial digunakan pasca erupsi Merapi 2010 beberapa tahun setelahnya. Sehingga dalam aktivitas diplomasi digital kedua bencana memiliki persamaan yakni sama-sama memanfaatkan media sosial, namun di tahapan manajemen bencana yang berbeda, jika di Jepang saat terjadi bencana, sedangkan di DIY setelah bencana berakhir setelah beberapa tahun yakni sekitar 2013 dengan fokus pada "Laporan Aktivitas Gunung Merapi".

Pada saat terjadinya erupsi DIY, upaya pendekatan info menggunakan handytalk/radio dan website pemerintah yang difungsikan untuk informasi tanggap darurat, cara-cara tradisional seperti menggunakan kentongan pun masih dilakukan. Perbedaan dalam penanganan kedua bencana secara struktural terletak 
pada level yang bertanggung jawab dalam manajemen bencana, di Jepang sendiri bencana gempa bumi dan tsunami di pegang kendali oleh pusat karena menjadi bencana nasional, sedangkan erupsi Merapi 2010 di pegang kendali provinsi dan kabupaten. Di Jepang, Facebook dan twitter sangat kuat pada saat itu, para korban mencoba menggunakan twitter dan facebook untuk mengirim SOS (alarm bantuan darurat). Kemudian dari daerah terdampak ke ibukota berjarak sekitar lima ratus kilometer jauhnya dari Tokyo, dan petugas Tokyo menggunakan twitter tersebut untuk daerah yang terdampak agar mengetahui kebutuhan korban. Informasi tersalurkan dengan sangat cepat, termasuk saat potensi tsunami terjadi. Informasi kenaikan air laut yang dibagikan oleh warga di media sosial membantu mempercepat evakuasi ketika tsunami menerjang wilayah Jepang bagian timur.

Sedangkan untuk bencana erupsi tahun 2010, perubahan mindset warga yang awalnya lebih mendahulukan informasi yang tidak scientifik, saat ini warga sudah mendahulukan informasi scientifik yang diinfokan BPPTKG atau BPBD. Upaya sosialisasi dan edukasi ke masyarakat melalui pertemuan langsung dan media sosial memberikan pengaruh positif. Seperti perubahan kenaikan status Merapi dari waspada ke siaga level III pada November 2020 yang diinfokan pemerintah, warga yang berada di zona bahaya langsung melakukan evakuasi dengan bantuan pemerintah, yang sebelumnya masih banyak warga yang lebih mendahulukan info dari juru kunci Merapi mengenai kondisi Merapi daripada pemerintah daerah. Berikut Penulis petakan dalam bentuk tabel aktivitas diplomasi digital di kedua bencana.

\begin{tabular}{|c|c|c|}
\hline $\begin{array}{c}\text { Aktivitas Diplomasi } \\
\text { Digital }\end{array}$ & $\begin{array}{c}\text { Bencana Erupsi Merapi Daerah } \\
\text { Istimewa Yogyakarta } 2010\end{array}$ & $\begin{array}{c}\text { Gempa Bumi, Tsunami, Nuklir } \\
\text { Jepang } 2011\end{array}$ \\
\hline $\begin{array}{l}\text { Agenda Setting } \\
\text { (Agenda informasi } \\
\text { dirancang melalui } \\
\text { media sosial oleh } \\
\text { pemerintah ke } \\
\text { masyarakat) }\end{array}$ & $\begin{array}{l}\text { Pemerintah dalam hal ini BPBD DIY } \\
\text { dan Sleman, BPPTKG, BMKG, saling } \\
\text { berkoordinasi merancang agenda } \\
\text { informasi yang disalurkan melalui } \\
\text { twitter Pusdalops DIY dan Sleman } \\
\text { yang dimiliki BPBD dan twitter } \\
\text { BPPTKG @BPPTKG setelah pasca } \\
\text { bencana sekitar tahun } 2013 \text { dengan } \\
\text { fokus pada informasi status Merapi } \\
\text { dan pencegahan resiko bencana yakni } \\
\text { "Laporan Aktivitas Gunung Merapi". } \\
\text { Selain memanfaatkan twitter, } \\
\text { pemerintah memiliki website sendiri } \\
\text { bernama Lapor Bencana Sleman dan }\end{array}$ & $\begin{array}{l}\text { Pemerintah dalam hal ini } \\
\text { Kementerian Bencana Jepang } \\
\text { dibawah kendali Perdana Menteri } \\
\text { bersama National Research Institute } \\
\text { dan Badan Meteorologi Jepang } \\
\text { yang mengumpulkan informasi } \\
\text { dengan sangat cepat melalui akun } \\
\text { twitter saat terjadinya bencana } \\
\text { Maret2011, lalu Japan Self-Defense } \\
\text { Forces (SDF)/ Pasukan Bela Diri } \\
\text { Jepang diterjunkan ke wilayah } \\
\text { terdampak melakukan evakuasi } \\
\text { korban. Agenda informasi } \\
\text { dirancang saat bencana terjadi }\end{array}$ \\
\hline
\end{tabular}




\begin{tabular}{|c|c|c|}
\hline & 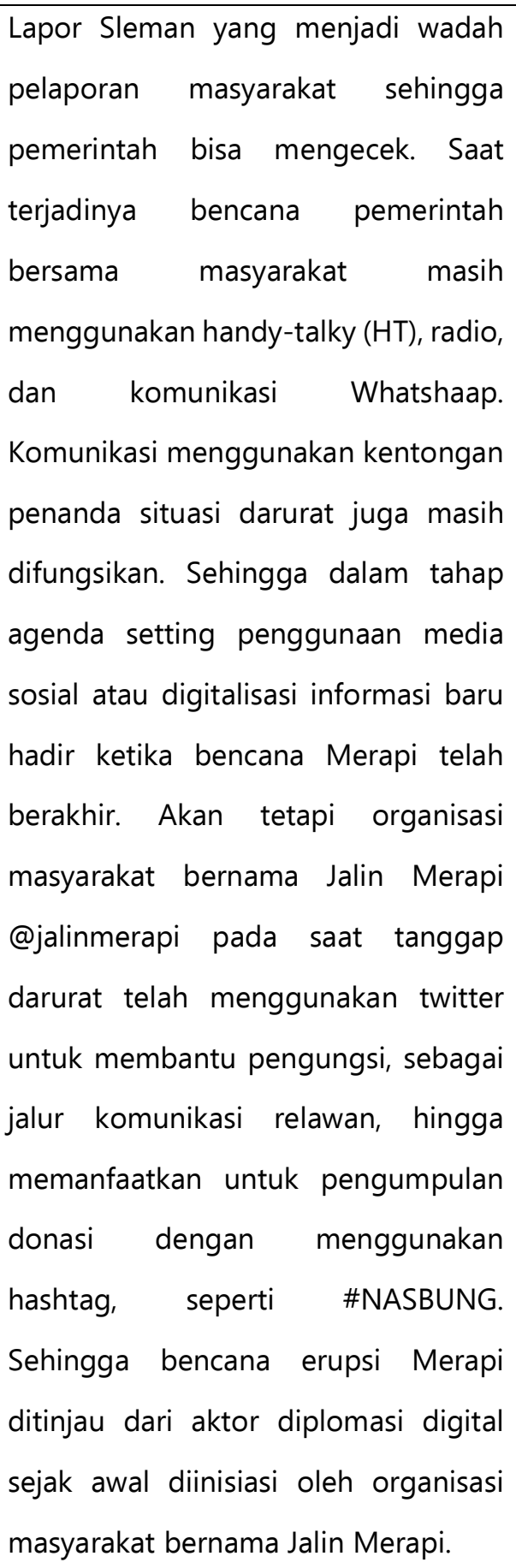 & $\begin{array}{l}\text { melalui media twitter. Sehingga } \\
\text { mendapatkan informasi situasi } \\
\text { masyarakat yang darurat butuh } \\
\text { bantuan. Adapun akun twitter } \\
\text { pemerintah pusat yang menjadi } \\
\text { wadah agenda pengaduan laporan } \\
\text { dengan akun @JPN_PMO. Namun } \\
\text { akun-akun twitter pemerintah lokal } \\
\text { juga mengalami peningkatan } \\
\text { followers. Selain twitter, media } \\
\text { komunikasi lain adalah Line. } \\
\text { Agenda informasi yang difokuskan } \\
\text { adalah tanggap darurat. Sedangkan } \\
\text { di Jepang sendiri, kendali penuh } \\
\text { pemanfaatan media sosial twitter } \\
\text { dilakukan sejak awal dilakukan oleh } \\
\text { pemerintah. Organisasi masyakarat } \\
\text { seperti Red Cross Japan. }\end{array}$ \\
\hline $\begin{array}{l}\text { Presence Explanation } \\
\text { (Agenda informasi } \\
\text { tersampaikan ke } \\
\text { masyarakat dan telah } \\
\text { terlihat tanggapan } \\
\text { berupa like, } \\
\text { reposting, atau } \\
\text { comment) }\end{array}$ & $\begin{array}{l}\text { Agenda informasi mendapatkan } \\
\text { perhatian dari warga dengan bukti } \\
\text { warga yang mem-follow, like, } \\
\text { reposting, dan memberikan komentar } \\
\text { akun twitter Pusdalops dan BPPTKG } \\
\text { setelah bencana berakhir. Namun } \\
\text { pemerintah tetap melakukan } \\
\text { pendekatan langsung ke warga. }\end{array}$ & $\begin{array}{l}\text { Agenda informasi mendapatkan } \\
\text { tanggapan dari warga dengan } \\
\text { memanfaatkan hashtag tagar (\#) } \\
\text { pengguna mencari informasi dan } \\
\text { mengunggahnya. Setelah gempa } \\
\text { hingga } 30 \text { Maret } 2011 \\
\text { menghasilkan 1.612.074 tweets } \\
\text { dengan menggunakan kata kunci }\end{array}$ \\
\hline
\end{tabular}




\begin{tabular}{|c|c|c|}
\hline & $\begin{array}{l}\text { Karena tidak semua warga memahami } \\
\text { media sosial. Informasi "Laporan } \\
\text { Aktivitas Gunung Merapi" di posting } \\
\text { lewat akun @BPPTKG yang membuat } \\
\text { jangkaun pesan menjadi sangat luas } \\
\text { dan postingan tersebut akan langsung } \\
\text { muncul di notifikasi pengikut BPPTKG } \\
\text { yang mencapai lebih dari } 164.000 \\
\text { akun. }\end{array}$ & $\begin{array}{l}\text { "Earthquake". Warga Jepang } \\
\text { memiliki tingkat melek teknologi } \\
\text { yang tinggi sehingga pemanfaatan } \\
\text { media sosial terakumulasi dengan } \\
\text { baik pada saat bencana. Saat ini } \\
\text { akun @JPN_PMO telah diikuti oleh } \\
246.000 \text { akun. }\end{array}$ \\
\hline $\begin{array}{l}\text { Conversation } \\
\text { Generating } \\
\text { (Pemahaman yang } \\
\text { sama antar } \\
\text { pemerintah dan } \\
\text { masyakarat terkait } \\
\text { agenda yang } \\
\text { dirancang terbentuk, } \\
\text { telah ada umpan } \\
\text { balik, dan terjadi } \\
\text { dialog) }\end{array}$ & $\begin{array}{l}\text { Baik pemerintah dan warga Jogja } \\
\text { melalui informasi yang terus } \\
\text { dilancarkan lewat media sosial, } \\
\text { memberikan pemahaman yang sama } \\
\text { antar kedua pihak. Hal ini dibuktikan } \\
\text { dengan perubahan mindset warga } \\
\text { yang awalnya lebih mendahulukan } \\
\text { informasi yang tidak scientifik, saat ini } \\
\text { warga sudah mendahulukan informasi } \\
\text { scientifik yang diinfokan BPPTKG atau } \\
\text { BPBD. Seperti perubahan kenaikan } \\
\text { status waspada ke siaga level III pada } \\
\text { November } 2020 \text { Merapi yang } \\
\text { diinfokan pemerintah, semua warga } \\
\text { memahami dan melakukan evakuasi } \\
\text { yang telah diatur oleh pemerintah } \\
\text { setempat. }\end{array}$ & $\begin{array}{l}\text { Facebook dan twitter sangat kuat } \\
\text { pada saat itu, para korban mencoba } \\
\text { menggunakan twitter dan facebook } \\
\text { untuk mengirim sos (alarm } \\
\text { bantuan darurat). Kemudian dari } \\
\text { daerah gempa sekitar lima ratus } \\
\text { kilometer jauhnya dari Tokyo, dan } \\
\text { petugas } \\
\text { Tokyo menggunakan twitter } \\
\text { tersebut untuk daerah yang } \\
\text { terdampak agar mengetahui } \\
\text { kebutuhan korban. Pemerintah dan } \\
\text { warga berkomunikasi lewat twitter } \\
\text { dan facebook. Informasi tersalurkan } \\
\text { dengan sangat cepat saat potensi } \\
\text { tsunami terjadi. Informasi yang } \\
\text { dibagikan oleh warga di media } \\
\text { sosial membantu } \\
\text { mempercepat evakuasi ketika } \\
\text { tsunami menerjang wilayah Jepang } \\
\text { bagian timur. }\end{array}$ \\
\hline
\end{tabular}

\section{SIMPULAN}

Dari penjelasan diatas dapat diambil kesimpulan bahwa proses aktivitas diplomasi digital yakni agenda setting, presence-expansion, dan conversation generating yang dilakukan pemerintah pusat hingga di level provinsi baik di bencana DIY dan Fukushima, Jepang secara aktif memanfaatkan akun media sosial 
seperti twitter dan facebook untuk proses manajemen bencana di pra bencana, saat bencana, dan pasca bencana. Aktivitas diplomasi digital yang dilakukan dari studi kasus dua daerah ini menunjukkan beberapa persamaan dan perbedaan. Pada bencana Erupsi Merapi 2010 di DIY, aktivitas diplomasi digital baru intens terbentuk setelah bencana berakhir, penggunaan twitter oleh pemerintah belum ada di tahun 2010 saat bencana terjadi, dan sekitar tahun 2013 baru secara terlembaga badan yang menaungi media sosial terbentuk yang bernama Pusat Pengendalian Operasi Penanggulangan Bencana (Pusdalops). Namun pada saat tanggap darurat, organisasi masyakaratlah yang sejak awal membuat akun twitter @jalinmerapi dan terbukti berhasil. Sedangkan di Jepang, pada saat bencana gempa bumi, tsunami, dan nuklir di Fukushima tahun 2011, aktivitas diplomasi digital telah terbentuk saat bencana terjadi tepatnya sehari setelah bencana, akun twitter menjadi platform yang masif digunakan oleh pemerintah yakni @JPN_PMO dan sebagai penyalur laporan dari masyarakat. Sehingga dapat disimpulkan bahwa penggunaan media sosial sabagai alat diplomasi digital dalam kebencanaan baik di DIY dan Fukushima, Jepang memiliki peran vital dan memiliki pengaruh yang besar bagi pemerintah dan masyarakat meskipun dalam tahap manajemen bencananya di kedua daerah ini berbeda.

\section{UCAPAN TERIMAKASIH}

Apresiasi kami sampaikan kepada KemenristekDIKTI yang telah mendanai penelitian ini melalui skema Hibah Penelitian Dosen Pemula (PDP) Tahun 2020.

\section{DAFTAR PUSTAKA}

Adesina, O. S. (2017). Foreign policy in an era of digital diplomacy. Cogent Social Sciences, 3, 1-13. https://doi.org/10.1080/23311886.2017.1297175

https://www.cogentoa.com/article/10.1080/23311886.2017.1297175

Bappenas, \& Bakornas PB. (2006). Rencana Aksi Nasional Pengurangan Resiko Bencana 2006-2009. Perum Percetakan Negara RI.

Bjola, C. (2016). Digital diplomacy - the state of the art. Global Affairs, 2(3), 297-299. https://doi.org/10.1080/23340460.2016.1239372

Bjola, C., \& Jiang, L. (2015). Social media and public diplomacy: A comparative analysis of the digital diplomatic strategies of the EU, Us and Japan in China. In Digital Diplomacy: Theory and Practice.

Blackburn, B. (2011). Japan Earthquake and Tsunami: Social Media Spreads News, Raises Relief Funds. ABC News. Retrieved July 20, 2012 from: http://www.abcnews.go.com BPBD. (2019) Pusdalops-PB. BPBD DIY. http://bpbd.jogjaprov.go.id/pusdalops-pb BNPB. (2009). Kajian Tentang Penanggulangan Bencana Alam Di Indonesia. In Oriental Consultants Co., Ltd. Asian Disaster Reduction Center (Vols. 2-2, Issue Japan International Cooperation). https://openjicareport.jica.go.jp/pdf/11928892.pdf 
BNPB. (2011). Indekks Rawan Bencana Indonesia.

BNPB. (2016). Risiko Bencana Indonesia (Disasters Risk of Indonesia). Direktorat

Pengurangan Risiko Bencana, BNPB. https://doi.org/10.1007/s13753-018-0186-5

BNPB. (2019). IRBI (Indeks Resiko Bencana Indonesia) Tahun 2018. In Direktorat

Pengurangan Risiko Bencana, BNPB. Direktorat Pengurangan Risiko Bencana, BNPB.

https://www.bnpb.go.id//uploads/renas/1/BUKU RENAS PB.pdf

BNPB, \& BAPPENAS. (2011). Rencana Aksi Rehabilitasi dan Konstruksi Pasca Bencana

Erupsi Gunung Merapi 2011-2013 (Issue Juni).

Cabinet Office Government of Japan. (2015).1-49.

http://www.bousai.go.jp/1info/pdf/saigaipanf_e.pdf

Coppola, D. P. (2011). Introduction to International Disaster Management. In

Introduction to International Disaster Management. https://doi.org/10.1016/C20090-64027-7

Dunbar, Paula. (2011). Tohoku Earthquake and Tsunami. Journal Geomatics, Matural Hazards and Risk. https://doi.org/10.1080/19475705.2011.632443

Great East Japan Earthquake. Overview International Situation and Japan's Diplomacy in 2011. https://www.mofa.go.jp/policy/other/bluebook/2012/html/h1/h1_03.html

Guay, T. (2000). Local Government and Global Politics: The Implications of Massachusetts' "Burma Law". Political Science Quarterly, 115(3), 353-376.

Hashimoto, Yasuaki. Ohama, Akihiro. (2014). The Role of Social Media in Emergency Response: The Case of the Great East Japan Earthquake. NIDS Journal of Defense and Security.

http://www.nids.mod.go.jp/english/publication/kiyo/pdf/2014/bulletin_e2014_6.pdf

Joo-Young Jung. (2012). Social Media Use and Goals After The Great East Japan

Earthquake. First Monday, Vol 17 Number 8-6.

https://firstmonday.org/ojs/index.php/fm/article/view/4071/3285

International Peace Institute. (2018). The Role of Local Governance in Sustaining Peace: Vol. February. https://www.ipinst.org/wp-content/uploads/2018/02/1802_LocalGovernance-and-Sustaining-Peace.pdf

Kaigo, Muneo. (2012) Social Media Usage During Disasters and Social Capital: Twitter and the Great East Japan Earthquake. Keio Communication Rewiew No. 34 http://www.mediacom.keio.ac.jp/publication/pdf2012/KCR34_02KAIGO.pdf Kampf, R., Manor, I., \& Segev, E. (2015). Digital Diplomacy 2.0? A Cross-national Comparison of Public Engagement in Facebook and Twitter. The Hague Journal of Diplomacy, 104), 331-362. https://doi.org/10.1163/1871191X-12341318

Kelman, I. (2017). Governmental duty of care for disaster-related science diplomacy. Disaster Prevention and Management: An International Journal, 26(4), 412-423. https://doi.org/https://doi.org/10.1108/DPM-02-2017-0031 Permanent 
Lennah, M. (2012). The Role of Public Diplomacy in Disaster Risk Reduction: a Case Study of the 2004 Indian Ocean Tsunami. UNIVERSITY OF NARIOBI.

Lune, H., \& Berg, B. L. (2017). Methods for the Social Sciences Global EditioN (Global edi). Pearson Education Limited.

Mahaswari, Mirah. (2012). Jalin Merapi: Penggunaan Media Baru dan Gerakan Sosial Penanggulangan Bencana. Vol 1, No. 2. Oktober 2012. Jurnal Komunikasi Indonesia http://journal.ui.ac.id/index.php/jkmi/article/viewFile/7821/3889

Merrill, Molly. (2011). Disaster in Japan Causes Spike in Social Media Use.

HealthcareITNews. https://www.healthcareitnews.com/news/disaster-japan-causesspike-social-media-use

Melissen, J., \& Caesar-Gordon, M. (2016). "Digital diplomacy" and the securing of nationals in a citizen-centric world. Global Affairs, 2(3), 321-330.

https://doi.org/10.1080/23340460.2016.1239381

Nicolson, H. (1950). Diplomacy (2nd editio). Oxford University Press.

Prakosa, Sigit. (2020). Peran BMKG dalam Informasi Bencana Melalui Media Sosial. Hasil Wawancara Pribadi: 6 September 2020, Kepala Kelompok Analisa dan Prakiraan Cuaca Stasiun Klimatologi Sleman

Japanese Government Internet TV. Public Relations Office, Cabinet Office, Government of Japan. https://nettv.gov-online.go.jp/eng/prg/prg2063.html?nt=1

Kushartati, Asih. (2020). Penanganan Bencana Erupsi 2010 melalui Media Sosial. Hasil

Wawancara Pribadi: 29 Agustus 2020, Sekretariat Badan Penanggulangan Bencana Daerah Kabupaten Sleman Daerah Istimewa Yogyakarta

Shaluf, I. M. (2007). An overview on disasters. In Disaster Prevention and Management: An International Journal. https://doi.org/10.1108/09653560710837000

Tatsumi, Yuki. (2011). The Role of the Japan Self-Defense Forces in the Great Eastern Japan Eartquake. The Stimson Center. https://www.stimson.org/2011/role-japanself-defense-forces-great-eastern-japan-earthquake/

Tsukamoto, Stefano. (2020). Penanganan Bencana Gempa Bumi Jepang 2011 dan Penggunaan Media Sosial. Hasil Wawancara Pribadi: 5 September 2020, Dosen dan Peneliti Manajemen Disaster Osaka University

United Nations International Strategy for Disaster Reduction (UNISDR). (2009). 2009 UNISDR Terminology on Disaster Risk Reduction. In United Nations. https://doi.org/10.1021/cen-v064n005.p003

Verrekia, Bridget. (2017). Digital Diplomacy and Its Effect for International Relations. Spring.

Viandrina, Milly Marsha. Aktivitas Diplomasi Digital Pemerintah Jepang Pasca Bencana Alam The Great East Japan Earthquake 2011-2016. Universitas Katolik Parahyangan. Retrieved from http://repository.unpar.ac.id/handle/123456789/5586 
Westcott, N. (2008). Digital Diplomacy: The Impact of the Internet on International Relations (Issue July).

Yin, R. K. (2015). Case Study Research: Design and Methods (5 Edition). Sage Publication Inc. 